\title{
Promotion of resistance of black alder clones (Alnus glutinosa (L.) Gaertn.) against Phytophthora alni ssp. alni by cyclolipopeptide producing bacteria
}

\author{
By I. ZASPEL ${ }^{1), *)}$, G. NAUJOKS ${ }^{1)}$, L. KRÜGER ${ }^{2)}$ and L. H. PHAM ${ }^{2)}$
}

(Received 11 ${ }^{\text {th }}$ March 2015)

\begin{abstract}
Summary
This study demonstrated the promotion of the ability of black alder clones to resist to Phytophthora alni ssp. alni with the cyclolipopeptide (CLP)-producing Pseudomonas veronii isolate PAZ1. The bacterial strain, isolated from an association with $P$. alni ssp. alni, and characterised by its production of the secondary metabolites viscosin and massetolides, possessed inhibitory ability against isolates of the oomycete tree pathogen in vitro. In plant experiments with alder clones in vitro, the treatment with living bacteria showed an earlier start of the rooting process and a promoted root and shoot growth. Compared to non-treated plants, the root system was improved by longer primary roots with abundant secondary roots. The treatment with a methanol extract prepared from strain PAZ1 had no comparable effect. After protective application of strain PAZ1 14 days before the pathogen, the disease incidence was lower and biomass production was higher than in the pathogen control. These results were completed by a greenhouse experiment for a period of 13 months. Bacteria application prior to the pathogen led to reduced Phytophthora incidence at two of five clones in the combined treatment.
\end{abstract}

Key words: in vitro, massetolide, Pseudomonas veronii PAZ1, tissue culture, viscosin.

\section{Introduction}

For about two decades, the aggressive species Phytophthora alni (Oomycetes) has been known as a pathogen on alder trees (Alnus spp.). The fungus causes lethal root and root collar rot (BRASIER et al., 1995 and 1999). In the beginning of its appearance, the disease has spread very quickly over the European distribution areas of alder species and has recently been found in Alaska (ADAMs et al., 2008). In Germany, the pathogen is present in the most riparian and forest alder stands. Black alder (A. glutinosa (L.) Gaertn.) is most frequently affected.

The pathogen can be divided into three subspecies varying in their pathogenicity (Ioos et al., 2006). The subspecies $P$. alni ssp. alni is currently the most aggressive type. This type has established itself widely in the Northern German lowlands. The development and

\footnotetext{
1) Johann Heinrich von Thünen Institute (TI), Institute of Forest Genetics, Eberswalder Chaussee 3A, D-15377 Waldsieversdorf, Germany.

2) Institut für Ökologie, Technische Universität Berlin, ErnstReuter-Platz 1, D-10587 Berlin, Germany.

*) Corresponding author: Dr. IRMTRAUT ZASPEL.

Phone: +49(0)33433157-190, Fax: +49(0) 33 43 3157-199

E-Mail: irmtraut.zaspel@ti.bund.de
}

degree of infection proceeds very differently and depends on site conditions, alder provenience, genotype, and tree age (GIBBs et al., 2003, SCHNECK and ZASPEL, 2006). In some localities very high losses have occurred while in others, the disease impact has been relatively weak (WEBBER et al., 2004). The causes of changes in the $P$. alni population and stagnating disease progress which was observed in some areas (CECH, 2001; GIBBS, 2003) are unclear. Specific antagonists could hitherto not be found.

In the course of preliminary investigations of the authors, strains of $P$. alni isolated from alders from natural sites were occasionally associated with specific bacteria which were detectable only on nitrogen-rich media but not on poor media like potato dextrose or oatmeal. The bacteria showed a broad resistance to standard antibiotics. One strain of these accompanying bacteria could be isolated from the hyphal surface oomycete mycelia and was identified as a member of the genus Pseudomonas named Pseudomonas veronii PAZ1. Although this strain came from a $P$. alni isolate, as a single organism the bacteria developed antagonistic activity in vitro against some $P$. alni strains and other fungal pathogens (KRÜGER, 2008).

Bacteria of the genus Pseudomonas have been described extensively in the literature as inhibitors of a wide range of plant pathogens and promoters of plant growth (WhIPPS, 2001; HAAS and DEFAGO, 2005; GANESHAN and Kumar, 2005; HöFTe and Altier, 2010). Furthermore, some species of Pseudomonas are involved in bacterial communities of fungal surfaces and frequent inhabitants of mycorrhiza formers, fungal pathogens and saprotrophs (DE BOER et al., 2005; NAZIR et al., 2010).

The investigation of secondary metabolite formation of $P$. veronii PAZ1 by methods of liquid chromatography and mass spectrometry as well as Nuclear Magnetic Resonance (NMR) revealed a range of cyclic lipopeptides (CLPs), among others the main CLP viscosin and isomeres of massetolides (KRÜGER, 2008). The CLP compounds produced by micro-organisms such as Pseudomonas species may serve different and multiple purposes, for example play a role in antagonistic interactions with other organisms and share functions like antimicrobial activity, biofilm formation, and motility (LAYCOCK et al., 1991; NiELSEN, 2002; De SouZA et al., 2003; RAAIJMAKERS et al., 2006 and 2010). The massetolide A-producing strain P. fluorescens SS101 was effective in preventing infection of tomatoes by Phytophthora infestans leading to a significant reduction in the expansion of late blight (TRAN et al., 2007). Former studies had shown that surfactant-producing Pseudomonas iso- 
lates possessed lytic activity against zoospores of multiple oomycete pathogens like Pythium and Phytophthora species (DE SouZA et al., 2003).

In the present work, results of the effect of the CLPproducing strain Pseudomonas veronii PAZ1 on the growth of black alder clone plants as well as on disease development after co-inoculation with a pathogenic P. alni ssp. alni strain are demonstrated.

\section{Material and Methods}

The investigation was carried out in two steps, in axenic culture in vitro and in vivo under greenhouse conditions.

\section{Establishing and propagation of alder clone plants}

Black alder seeds were harvested from trees with differently pronounced disease symptoms growing in the marshland region of the river Oder. Seed batches No. 4 and 8 derived from outwardly healthy trees, whereas No. 5 and 12 were picked from strongly affected ones. The seeds were sown in the greenhouse, and after 6 to 12 months the seedlings were cut up to shoot tips and nodal segments. After surface disinfection with $0.25 \%$ mercury chloride and subsequent rinsing in deionised water, the explants were transferred to tissue culture conditions. The clone establishment was successful on modified Woody Plant Medium (WPM, Duchefa Biochemie BV, The Netherlands, according to LLOYD and McCown, 1980) supplemented with $3.5 \mu \mathrm{M}$ zeatin as growth regulator and solidified by $0.8 \%$ Phytoagar in Erlenmeyer flasks $(100 \mathrm{ml})$ were filled with $25 \mathrm{ml}$ nutrient medium and covered with aluminium foil before autoclaving at $121^{\circ} \mathrm{C}$ (pressure: $105 \mathrm{kPa}$ ) for $20 \mathrm{~min}$. Shoot cultures were grown at 20 to $23^{\circ} \mathrm{C}$ with an irradiance of 27.5 to $28 \mu \mathrm{mol} \mathrm{m} \mathrm{m}^{-2} \mathrm{~s}^{-1}$ supplied by warm-white fluorescent tubes (day:night $=16: 8$ hours). Once per month, elongated shoots were cut up and shoot tips and nodal segments were transferred to fresh nutrient medium. For production of complete plants, 15-20 mm-long shoots were rooted on WPM with half concentrated macro and micro nutrients, $0.49 \mu \mathrm{M}$ IBA and $0.27 \mu \mathrm{M}$ NAA. After two weeks, rooted plantlets were transferred to commercial propagation soil containing peat, perlite, clay and a low amount of fertiliser ("Einheitserde, Typ VM") and were grown under high humidity in the greenhouse (plastic tunnels with mist irrigation). After successive hardening, the black alder clone plants were ready for inoculation experiments in the greenhouse.

\section{Propagation of P. alni}

Isolates of $P$. alni ssp. alni, obtained from damaged trees of alder stands in Eastern Germany (marshland region of river "Oder") in 2007-2008, were grown on carrot agar (CA: carrot pieces 5\%, agar-agar $1.5 \%$ per 1000 $\mathrm{ml}$ deionized water, $\mathrm{pH}$ 6.0) at $20^{\circ} \mathrm{C}$ for 20 days. For this study, the strains AL5, WU1, and WU7 from three different trees of two separate stands were used.

\section{Propagation of Pseudomonas veronii PAZ1}

The bacteria strain, originally isolated from hyphae of a $P$. alni ssp. alni culture in 2008, designated to
Pseudomonas veronii PAZ1, was grown on M1 agar (malt extract $1 \%$, yeast extract $0.4 \%$, glucose $0.4 \%$, agar-agar $1.5 \%, \mathrm{pH} 7.0$ ) for 6 to 7 days. Bacterial suspensions for plant treatment were prepared with cells scraped from plates and adjusted with sterile tap water to $10^{8}$ cells per ml.

The ITS1/4 region of $16 \mathrm{~S}$ rDNA of the strain Pseudomonas veronii PAZ1 used in this work, was sequenced (GATC Konstanz, Germany) and the resulting sequence with a total length of 1392 bp was deposited in GenBank under the accession number KP858504.

\section{Extraction of secondary metabolites from PAZ1}

Pseudomonas veronii PAZ1 was grown on M1 agar for 10 days. Afterwards, an extraction with methanol followed, including a threefold ultrasonic treatment, each for 30 minutes. The methanol was removed with a rotary evaporator and the mixture was dried via lyophilisation. The metabolites were resolved with methanol and dried after centrifugation. For a complete extraction, the residue was extracted with ethyl acetate, dried and merged with the methanol extract. For separation of the CLP fraction, the dried methanol extract was first dissolved in $10 \mathrm{ml} \mathrm{H}_{2} \mathrm{O}$ and applied on two solid phase extraction cartridges (Oasis HLB, Waters). The residue was dissolved in $5 \mathrm{ml}$ methanol, diluted 3:1 with $\mathrm{H}_{2} \mathrm{O}$ and also applied. The CLP fraction was eluted with pure methanol.

\section{Plant experiments under axenic conditions}

Glass tubes (95 mm long with $28 \mathrm{~mm}$ diameter) were filled with $7.5 \mathrm{ml}$ of modified half-concentrated WPM and closed with aluminium foil. A part of the water for medium formulation (20\%) was substituted by carrot water which was prepared by cooking $50 \mathrm{~g}$ carrot pieces in $200 \mathrm{ml}$ water for $20 \mathrm{~min}$. After removing the carrot pieces, the liquid was used to fill up the medium to one litre. As gelling agent, 1.2\% Phytoagar was used. Alder shoots from shoot propagation in vitro with a length of 10 to $20 \mathrm{~mm}$ were transplanted into tubes, and cultivated at $20^{\circ} \mathrm{C}$ for 8 weeks under the light conditions described above for tissue culture.

\section{Pathogenicity experiment 1 in vitro}

The influence of $P$. alni and of living Pseudomonas veronii PAZ1, as well as its secondary metabolite extract, applied solely and in combination on growth and vitality of alder clone plants was examined.

Inoculation of alder shoots with the pathogen in axenic culture was done by placing a small agar plug $(2 \times 2 \mathrm{~mm})$ overgrown with mycelium of the isolate AL5 directly beside the shoot base of shoot tips harvested from tissue culture shortly before. For inoculation of axenically growing plants, the shoots of the latter were dipped into the suspension (preparation see above) before transfer to the test medium.

Enrichment of plant medium by metabolite extract was applied by adding $3 \mathrm{ml} / \mathrm{L}$ to the warm $\mathrm{CA}$ medium (48 to $50^{\circ} \mathrm{C}$ ). One control medium was prepared with the same amount of methanol added to the warm agar for the comparison of secondary metabolite extract of 
bacteria and one control with untreated shoots was included. The co-inoculation with the pathogen was performed at the same time. Four alder clones were tested $(12 / 55,8 / 65,5 / 7$, and $4 / 5)$. The first number of the clone label is referring to the mother tree the seeds were harvested from. Each variant contained 25 ramets.

\section{Pathogenicity experiment 2 in vitro}

Shoots from three alder clones $(8 / 65,5 / 7$, and 4/5)were co-cultivated with living bacteria of $P$. veronii PAZ1 on CA medium for two time periods ( 7 days and 14 days, respectively) before inoculation with the pathogen using
P. alni agar plugs was executed as described above. Each treatment respectively control variant comprised 25 ramets.

The total observation time was eight weeks for both in vitro experiments.

Root development and disease symptoms were evaluated after four weeks (experiment 1) and three weeks (experiment 2), respectively for the first time, and then weekly. Root formation was evaluated by a 5-class scale $(1=$ no roots, $2=$ roots not longer than $2 \mathrm{~mm}, 3=$ roots not longer than $10 \mathrm{~mm}, 4$ = formation of primary roots longer than $10 \mathrm{~mm}, 5=$ formation of primary roots

Table 1. - Experiment 1: Fresh weight (FW) of shoots and roots and shoot development of alder clones in vitro after 8 weeks cultivation time following treatments with Pseudomonas veronii PAZ1, Phytophthora alni, methanolic metabolite extract of $P$. veronii PAZ1 alone or in combination with $P$. alni and influence of the treatments on rooting quality (values indicated with the same letter are not significantly different according to the Tukey-test, $\mathrm{p}<0.05)$.

\begin{tabular}{|c|c|c|c|c|c|c|}
\hline Clone & $\begin{array}{l}\text { Treatment } \\
\text { No. }\end{array}$ & Ireatment & $\begin{array}{c}\text { Shool FW } \\
\text { (mg) }\end{array}$ & $\begin{array}{l}\text { Rool FW } \\
\text { (Ing) }\end{array}$ & $\begin{array}{c}\text { Shoot lenglh } \\
\text { (nim) }\end{array}$ & $\begin{array}{l}\text { No. of plants with } \\
\text { long main roots } \\
\text { (score } 4-5 ; n=25 \text { ) }\end{array}$ \\
\hline \multirow[t]{6}{*}{$12 / 55$} & 1 & Control (untreated) & $59 \mathrm{~b}$ & $42 \mathrm{ab}$ & $14.8 \mathrm{bod}$ & 10 \\
\hline & 2 & Control (Methanol) & $50 \mathrm{~b}$ & $61 \mathrm{a}$ & $14.1 \mathrm{~cd}$ & 21 \\
\hline & 3 & Pscudomonas PAZ1 & $75 \mathrm{a}$ & $63 \mathrm{a}$ & $15.8 \mathrm{abc}$ & 18 \\
\hline & 4 & P.alni & $27 \mathrm{c}$ & $0 \mathrm{c}$ & $13.2 \mathrm{~d}$ & 0 \\
\hline & 5 & Pscudomonas PAYI cxtract & $55 \mathrm{~b}$ & $21 \mathrm{bc}$ & $17.1 \mathrm{a}$ & 9 \\
\hline & 6 & Pscudomonas PAZl extract $+P$. alhi & $31 \mathrm{c}$ & $0 \mathrm{c}$ & $16.6 \mathrm{ab}$ & 0 \\
\hline \multirow[t]{6}{*}{$8 / 65$} & 1 & Control (untreated) & $52 \mathrm{~b}$ & $14 \mathrm{~b}$ & $17.9 \mathrm{e}$ & 14 \\
\hline & 2 & Control (Mcthanol) & $39 \mathrm{c}$ & $39 \mathrm{c}$ & $19.2 \mathrm{bc}$ & 0 \\
\hline & 3 & Psaddomonas PAZI & $72 \mathrm{~d}$ & $51 \mathrm{a}$ & $22.8 \mathrm{a}$ & 16 \\
\hline & 4 & P.alni & $25 \mathrm{~d}$ & $0 \mathrm{c}$ & $21.4 \mathrm{ab}$ & 0 \\
\hline & 5 & Pseudomonas PAZ1 extract & $52 \mathrm{~b}$ & $6 c$ & $20.6 \mathrm{ab}$ & 0 \\
\hline & 6 & Pseudomonas PAZl extract $+P$. almi & $29 \mathrm{~d}$ & $0 \mathrm{c}$ & $21.8 \mathrm{ab}$ & 0 \\
\hline \multirow[t]{6}{*}{$5 / 7$} & 1 & Control (untreated) & 5) b & $7 \mathrm{~b}$ & $17.5 \mathrm{bc}$ & 10 \\
\hline & 2 & Control (Methanol) & $58 \mathrm{~b}$ & $4 \mathrm{~b}$ & $17.6 \mathrm{bc}$ & 6 \\
\hline & 3 & Pseudomonas PAZI & $100 \mathrm{a}$ & 57 a & $20.3 \mathrm{a}$ & 21 \\
\hline & 4 & P. ulni & $35 \mathrm{~b}$ & $0 \mathrm{~b}$ & $17.0 \mathrm{c}$ & 0 \\
\hline & 5 & Pseudomonas PAZl cxtracl & $6.5 \mathrm{~b}$ & $7 \mathrm{~b}$ & $19.3 \mathrm{ab}$ & 6 \\
\hline & 6 & Psedamonas PNZI extract $+P$, alni & $34 \mathrm{~b}$ & $0 \mathrm{~b}$ & $18.8 \mathrm{abc}$ & 0 \\
\hline \multirow[t]{6}{*}{$4 / 5$} & 1 & Control (untreated) & $50 \mathrm{c}$ & 11 he & $14.4 \mathrm{c}$ & 7 \\
\hline & 2 & Control (Mcthanol) & $62 \mathrm{~b}$ & $9 \mathrm{bc}$ & $16.0 \mathrm{bc}$ & 18 \\
\hline & 3 & Pseradomonas PAZI & 90 il & $73 a$ & $17.7 \mathrm{ab}$ & 25 \\
\hline & 4 & P.alni & $37 \mathrm{~d}$ & $0 \mathrm{c}$ & 19.7 a & 0 \\
\hline & 5 & Pseudomonas PAZI extract & $62 \mathrm{~b}$ & $13 b$ & $19.9 \mathrm{a}$ & 16 \\
\hline & 6 & Pseudomonas PALI extratet $+P$. alni & $39 \mathrm{~d}$ & $0 \mathrm{c}$ & $18.4 a b$ & 0 \\
\hline
\end{tabular}

Table 2. - Experiment 1: Comparison of the distribution of rooting scores of alder clones after 8 weeks cultivation time; data indicating p-values of Wilcoxon rank sum test; for treatments see Table 1.

\begin{tabular}{|l|c|c|c|c|}
\hline \multirow{3}{*}{ Clone } & \multicolumn{4}{|c|}{ Amount of rooted plants } \\
\cline { 2 - 5 } & \multicolumn{4}{|c|}{ Comparison between treatments } \\
& 1 vs. 3 & 1 vs. 4 & 2 vs. 5 & 2 vs. 6 \\
$12 / 55$ & 0.0434 & $<0.0001$ & 0,0002 & $<0.0001$ \\
\hline $8 / 65$ & $<0.0001$ & $<0.0001$ & 0.3773 & 0.0002 \\
$5 / 7$ & 0.2822 & $<0.0001$ & 0.8489 & $<0.0001$ \\
$4 / 5$ & 0.0063 & $<0.0001$ & 0.5845 & $<0.0001$ \\
\hline
\end{tabular}


longer than $10 \mathrm{~mm}$ with secondary roots and partly formation of dark root cortex). The damage caused by $P$. alni was evaluated using a 4 -class scale $(1=$ dead shoots or leaves with severe necroses, $2=$ brown discolorations and necroses on most leaves, $3=$ dark discolorations and small necroses, $4=$ green plants). After eight weeks, shoot length and fresh weight of shoots and roots were assessed.

\section{Plant experiment in the greenhouse}

The effect of $P$. veronii PAZ1 alone and together with $P$. alni was studied in a greenhouse experiment with potted alder clone plants. Rooted plants of the five clones $4 / 12,4 / 60,8 / 25,8 / 65$, and $12 / 55$ were transferred from tissue culture to single pots with $350 \mathrm{~g}$ soil (commercial growth substrate mixed with sand, 4:1) in May 2009. After cultivation under high humidity for 2 weeks, they were gradually hardened. Seventeen days after transfer of plantlets from tissue culture, bacteria suspension was prepared as described above. Two $\mathrm{ml}$ of a suspension of $10^{9}$ cells $\mathrm{ml}^{-1}$ were applied around the shoot base.

The application of $P$. alni by zoospores was carried out in August 2009. The preparation of inoculum suspension was carried out using a zoospore mixture of three isolates AL5, WU1 and WU7. The overgrown plates (CA) were covered with tap water which was exchanged daily. Three leaves of alder plants from tissue culture were added per plate. Sporangia with motile zoospores were produced at $15^{\circ} \mathrm{C}$ after 6 to 8 days. Because the sporangia production of the three used $P$. alni strains was approximately equal, the zoospore suspension was mixed in the same ratio and was adjusted to $10^{6}$ spores per $\mathrm{ml}$. Three $\mathrm{ml}$ were applied directly to the shoot base of alder plants.

A total of 30 replications was used for each of both treatments. The plants were cultivated in the greenhouse for 13 months. Pots treated by $P$. alni were separated from the pots without pathogen treatment to prevent the transfer of zoospores by moisture droplets. Temperature and light conditions followed the natural course as closely as possible. During winter months, the greenhouse temperature was kept above zero. At the end of September 2009, shoot length was measured for the first time. The experiment was finished in June 2010 with an assessment of growth traits (shoot length, weight of shoot and root system) and an evaluation of disease incidence which was scored visually by counting the number of plants with necrotic lesions on shoots caused by $P$. alni.

\section{Statistics}

All data resulting from plant growth experiments were analysed statistically using the SAS 9.2 software (SAS Institute Cary, NC, USA). Interactions between treatments, plant weight and shoot length were analysed by ANOVA followed by Tukey test with $\mathrm{P}<0.05$. A comparison of rooting frequencies and extent of disease incidence between the samples were tested by Wilcoxon rank sum test at the threshold of $\mathrm{P}=0.05$.

\section{Results}

\section{Axenic plant experiments}

Results of tests under in vitro conditions showed distinct differences of shoot and root growth between the

Table 3. - Experiment 2: Fresh weight (FW) of shoots and roots and shoot length of alder clones in vitro after 8 weeks cultivation time following treatments with Pseudomonas veronii PAZ1 alone and in combination with Phytophthora alni at two inoculation dates and influence of the treatments on rooting and disease severity (values indicated with the same letter are not significantly different according to the Tukey-test, $\mathrm{p}<0.05$ ).

\begin{tabular}{|c|c|c|c|c|c|c|c|}
\hline Clone & $\begin{array}{l}\text { Treatment } \\
\text { No. }\end{array}$ & Treatment & $\begin{array}{l}\text { Shoot FW } \\
\text { (mig) }\end{array}$ & $\begin{array}{l}\text { Root FW } \\
\text { (mg) }\end{array}$ & $\begin{array}{l}\text { Shoot } \\
\text { length } \\
\text { (mm) }\end{array}$ & $\begin{array}{l}\text { No. of plants with } \\
\text { long main roots } \\
\text { (score } 4-5 ; n=25)\end{array}$ & $\begin{array}{l}\text { No. of plants } \\
\text { with severe } \\
\text { symptoms on } \\
\text { shoots } \\
\text { (score } 1-2 ; n=25 \text { ) }\end{array}$ \\
\hline $8 / 65$ & 1 & Control (untreated) & 92 a & $16 \mathrm{~b}$ & $20.9 a$ & 25 & - \\
\hline & 2 & Pseadomonas $\mathrm{PAZ1}$ & $98 \mathrm{a}$ & $22 a$ & $18.9 \mathrm{a}$ & 23 & - \\
\hline & 3 & $\begin{array}{l}\text { Pseadomomas PAZ1 }+I^{2} \text {. alni added } \\
7 \text { days after bacteria inoculation }\end{array}$ & $43 c$ & $10 \mathrm{c}$ & $19.2 \mathrm{a}$ & 13 & 22 \\
\hline & 4 & $\begin{array}{l}\text { Pscadomonas PAZI + P. alni added } \\
14 \text { days after bacteria inoculation }\end{array}$ & $7] \mathrm{b}$ & $15 \mathrm{~b}$ & $18.9 \mathrm{a}$ & 20 & 12 \\
\hline $5 / 7$ & 1 & Control (untreated) & $81 \mathrm{~h}$ & $9 \mathrm{c}$ & $17.9 \mathrm{c}$ & 16 & - \\
\hline & 2 & Pseudomonas $\mathrm{P} \wedge \mathrm{Z}, 1$ & $119 a$ & $19 a$ & $22.8 \mathrm{a}$ & 25 & - \\
\hline & 3 & $\begin{array}{l}\text { Piezdomones PAZ1 }+f^{3} \text {. alni added } \\
7 \text { days after bacteria inoculation }\end{array}$ & $64 \mathrm{~b}$ & $12 \mathrm{bc}$ & $21.2 \mathrm{ab}$ & 25 & 18 \\
\hline & 4 & $\begin{array}{l}\text { Picudomonas PAZI + I'. alni added } \\
14 \text { days after bacteria inoculation }\end{array}$ & $79 \mathrm{~b}$ & $16 \mathrm{ab}$ & $19.7 \mathrm{bc}$ & 25 & 15 \\
\hline $4 / 5$ & 1 & Control (unlreated) & $88 \mathrm{~b}$ & $13 \mathrm{~b}$ & $19.7 b x$ & 24 & - \\
\hline & 2 & Pseudonomas PAZ1 & 135 a & $36 a$ & $22.1 \mathrm{a}$ & 25 & - \\
\hline & 4 & $\begin{array}{l}\text { Pseudomonas } \mathrm{PAZ} 1+P . \text { almi added } \\
7 \text { days after bacteria inoculation } \\
\text { Pseudomonas } \mathrm{PAZ1}+P \text {. alni added } \\
14 \text { days after bacteria inoculation }\end{array}$ & $86 b$ & $20 \mathrm{~b}$ & $\begin{array}{l}18.0 \mathrm{c} \\
21.5 \mathrm{ab}\end{array}$ & $\begin{array}{l}24 \\
24\end{array}$ & $\begin{array}{l}19 \\
10\end{array}$ \\
\hline
\end{tabular}


Table 4. - Experiment 2: Comparison of rooting frequencies and of severe disease symptoms (score 1-2) on shoots after 8 weeks cultivation time; data indicating p-values of Wilcoxon rank sum test; for treatments see Table 2.

\begin{tabular}{|l|c|c|c|c|c|c|c|}
\hline \multirow{2}{*}{ Clone } & \multicolumn{5}{|c|}{$\begin{array}{c}\text { Amount or rooted plants } \\
\text { Comparison between treatments } \\
\text { P. alni on shoots }\end{array}$} \\
\cline { 2 - 8 } & 1 vs. 2 & 1 vs.3 & 1 vs. 4 & 2 vs. 3 & 2 vs. 4 & 3 vs. 4 & 3 vs. 4 \\
\hline $8 / 65$ & 0.0514 & $<0.0001$ & 0.0184 & 0.0013 & 0.6153 & 0.0107 & $<0.0001$ \\
\hline $5 / 7$ & 0.0001 & 0.0010 & $<0.0001$ & 0.2743 & 0.3020 & 0.0437 & 0.2404 \\
$4 / 5$ & 0.0296 & 0.0058 & 0.0131 & 0.0044 & 0.0771 & 0.0886 & 0.0179 \\
\hline
\end{tabular}

alder clones and the effects of clone, treatment and clone $\mathrm{x}$ treatment interaction were statistically significant $(\mathrm{p}<0,001)$. The best shoot growth was observed for clone 5/7 (Experiment 1) and 4/5 (Experiment 2), respectively, and the best root growth for clone 12/55 (Experiment 1) and 4/5 (Experiment 2), respectively (Tables 1 to 4 ).

The treatment of non-rooted shoots with living bacteria of $P$. veronii PAZ1 resulted in increased root and shoot growth in the majority of clones. The clone 12/55 possessed a high spontaneous rooting ability but the rooting was further supported by the bacteria treatment. The shoot length was forced as well for some clones. Compared to untreated control plants, the root systems had significantly higher fresh weights with a higher portion of long primary roots with abundant secondary roots. This effect was confirmed in the two independent experiments in vitro.
The treatment with bacteria initiated an earlier start of root formation which could be observed clearly in both experiments (Figure 1 and 2). The development of long main roots was completed 2 to 3 weeks earlier than at control plants. Addition of the secondary metabolite extract of PAZ1 to the growth medium (Experiment 1) had no effect on shoot biomass formation. It caused a weak inhibition of root formation, whereby a weak increase of shoot length was recorded (Table 1). The application of the pathogen alone prevented the rooting completely. Most plantlets died or developed necroses on shoots with sporangia formation. The combination of Pseudomonas extract with $P$. alni did not prevent the harmful influence of the pathogen on alder shoots.

In contrast, the results of the treatment with living bacteria and time-delayed $P$. alni inoculation indicated that $P$. veronii PAZ1 was able to partly or completely

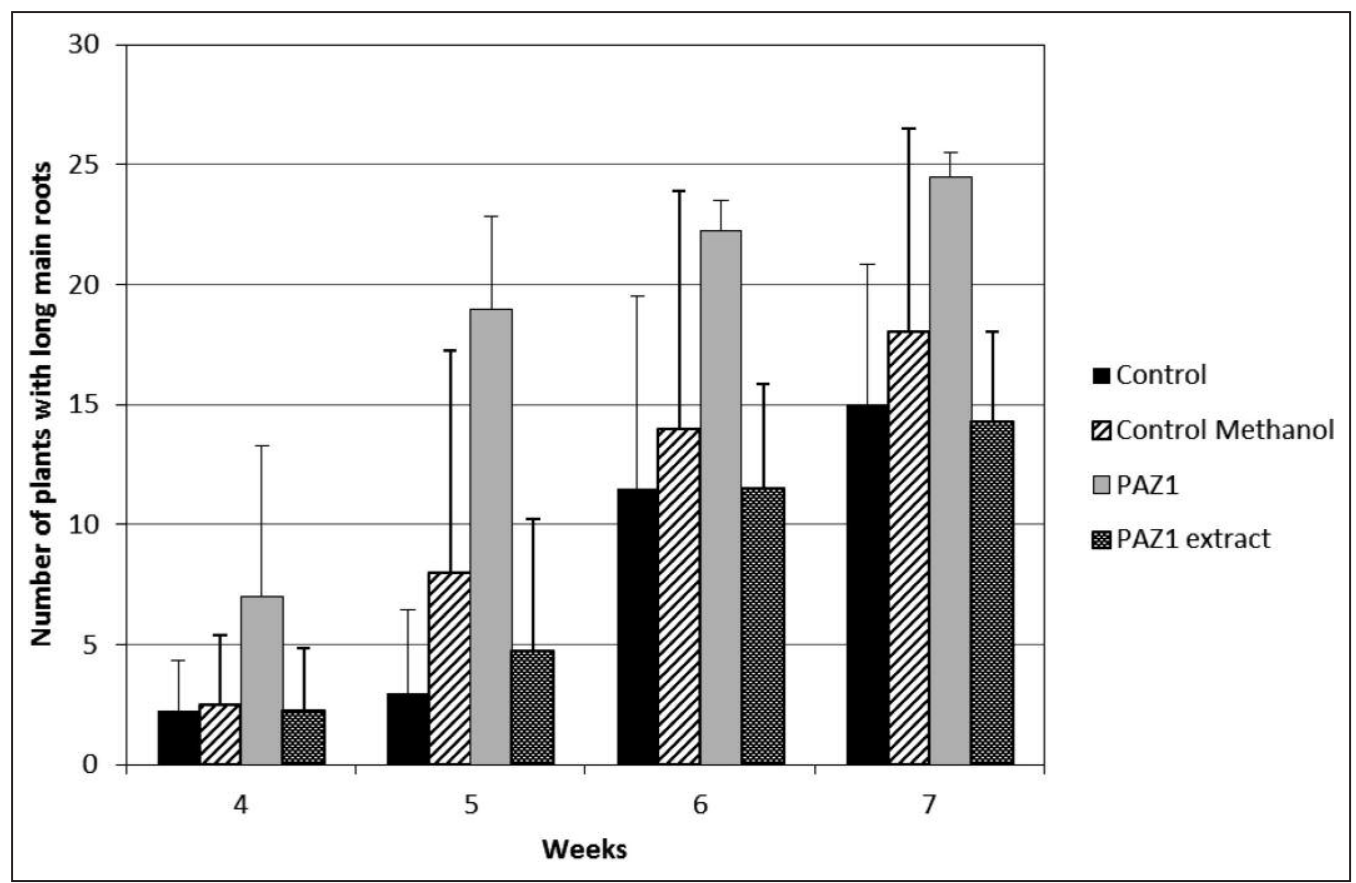

Figure 1. - Experiment 1: Rooting course of plants from four alder clones after treatment with living Pseudomonas veronii PAZ1 or with extract of the bacteria during 7 weeks (number of plants with scored root structure from 4-5). 


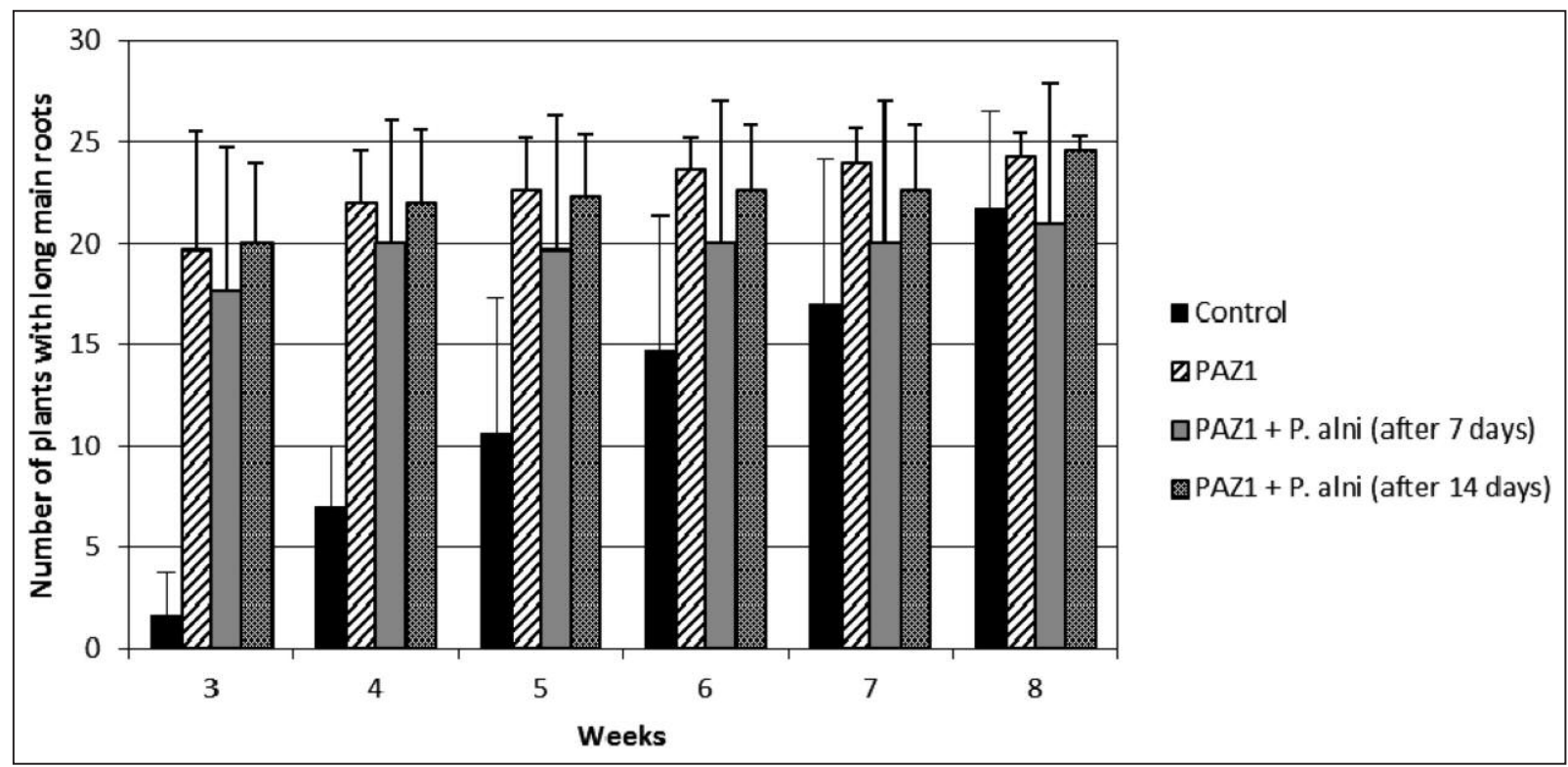

Figure 2. - Experiment 2: Rooting course of three alder clones after treatment with living Pseudomonas veronii PAZ1 alone and in combination with $P$. alni during 8 weeks (number of plants with scored root structure from 4-5).

Table 5. - Number of alder clone plants with disease symptoms caused by Phytophthora alni in the greenhouse experiment after 13 months: Comparison of treatments by P. alni alone and in combination with Pseudomonas veronii PAZ1 ( $\mathrm{n}=30)$.

\begin{tabular}{|c|c|c|c|c|}
\hline Clone & Treatment & No. of living plants & $\begin{array}{l}\text { No. of plants with } \\
\text { discase symptoms }\end{array}$ & $\begin{array}{l}\text { Significance (Wilcoxon rank sum } \\
\text { test, p-value) }\end{array}$ \\
\hline \multirow[t]{2}{*}{$12 / 55$} & P.almi & 30 & 20 & \multirow[b]{2}{*}{0.1942} \\
\hline & Pseudomonas PA7.1 + P. alni & 30 & 15 & \\
\hline \multirow[t]{2}{*}{$4 / 12$} & P.alni & 27 & 20 & \multirow[b]{2}{*}{0.00007} \\
\hline & Pseudomonas PAZ1 + P. alni & 26 & 7 & \\
\hline \multirow[t]{2}{*}{$4 / 60$} & P.alni & 25 & 18 & \multirow[b]{2}{*}{$<0.0001$} \\
\hline & Pseudomonas PAZ1 +P. alni & 30 & 7 & \\
\hline \multirow[t]{2}{*}{$8 / 25$} & P.alni & 25 & 14 & \multirow{4}{*}{0.8446} \\
\hline & Pseudomonas PAZ1 + P. alni & 30 & 16 & \\
\hline \multirow[t]{2}{*}{$8 / 65$} & P. alni & 30 & 11 & \\
\hline & Pseudomonas PAZ1 + P. alni & 30 & 9 & \\
\hline \multirow{2}{*}{$\begin{array}{l}\text { lotal of } \\
\text { all clones }\end{array}$} & P.alni & 137 & 83 & \multirow[b]{2}{*}{$<0,0001$} \\
\hline & Preudomonas PAZ1 + P. alni & 146 & 49 & \\
\hline
\end{tabular}

compensate the harmful effects of the pathogen on biomass production and number of diseased alder plants with severe symptoms (Tables 3 and 4 ). The effect of the treatment was significant at two of the three tested clones only, when the bacteria were applied two weeks before the pathogen.

\section{Greenhouse experiment}

As already was noted in the axenic plant experiments, significant growth differences of shoot biomass and length between alder genotypes were also determined in the greenhouse experiment. Compared to the most vigorous clone $8 / 65$, the clone $4 / 60$ showed a below average growth, and possessed only $61 \%$ of shoot length and $37 \%$ of shoot biomass after the cultivation period of one year.

In contrast to the experiments in vitro, differences of shoot length and biomass between the treatments could not be observed under non-sterile conditions in soil, neither after 16 weeks, nor after 13 months (data not shown). However, after the combined inoculation with bacteria and $P$. alni in the greenhouse, the number of plants with necrotic lesions on shoots was significantly reduced in two of five alder clones, also in the total number of alder clone plants (Table 5).

\section{Discussion}

This work presents results on the effect of a selected bacteria strain on growth and susceptibility against the serious oomycete pathogen $P$. alni on alder clones. The micropropagation technique allowed fast preparation of black alder clone material to evaluate the plant response in inoculation tests with the strain $P$. veronii PAZ1 originally living in association with the pathogen. The strain attracted attention because of its production of secondary metabolites, e.g. CLPs, with known and unknown structures (KRÜGER, 2008), which had shown an antibiotic activity against strains of the fungus-like pathogen $P$. alni ssp. alni in vitro (data not shown). 
CLP-producing Pseudomonas strains were found in many natural habitats, water reservoirs, plant cultivation systems, and also in and on fungal hyphae (RAAIJMAKERS, 2010; Musch and Alatossava, 2002). The frequency of CLP-producing strains compared to the total Pseudomonas population is strongly alternating and amounted, for example, in Dutch agricultural soils to 1-5\% (DE SouzA et al., 2003). The functions of CLPs in natural habitats have been described as antagonistic towards other microorganisms and beneficial for the mobility to new niches (RAAIJMAKERS et al., 2006).

The results of the present study indicate that the bacterial strain $P$. veronii PAZ1, when applied to alder clone plants, operated in two directions. The plant tests under axenic conditions demonstrated a clear growth-promoting effect by the living bacteria, especially an increased formation of root biomass followed by enhanced shoot growth. A growth-promoting effect by the secondary metabolite fraction extracted from cultures of Pseudomonas strain PAZ1 was not detected. The stimulating effect of strain PAZ1 on alder growth may be caused by phytohormone production (IAA, cytokinines, GA) and improved plant nutrition (solubilization of phosphates, associative nitrogen fixation, increased iron uptake). These are two important mechanisms by which plant growth promoting Pseudomonas strains can directly affect the plant development (PODILE and KISHORE, 2006). However, in complex environments under nonsterile soil conditions, it seems very difficult to ensure the growth promoting activity of inoculated bacteria over longer periods. In contrast to the experiments in vitro, it cannot be stated that the inoculation with $P$. veronii PAZ1 had a measurable impact on growth of alder clone plants in the greenhouse experiment.

Nevertheless, the bacteria had a suppressive effect against $P$. alni on alder clones in vitro and in vivo if they were given time advantage. This head-start seems to be necessary for the successful propagation of the inoculant and for colonizing the plant. The effect of disease suppression was still apparent after one year under semicontrolled greenhouse conditions. The observed effects are obviously, besides other factors, related to the production of viscosin by strain PAZ1. Viscosin is a CLP produced by pseudomonads. It possesses biosurfactantlike and antimicrobial properties, and has been successfully tested against the root pathogenic microorganisms Pythium ultimum, Rhizoctonia solani, and Sclerotium rolfsii (NIELSEN et al., 1999; ANDERSEN et al., 2003; LE et al., 2012). Moreover, a direct action of viscosin against oomycetes was detected by inhibition of zoospores motility and promoted lysis (DE BRUIJN et al., 2007). Biosurfactants play a role in the distribution of microorganisms on plant surfaces as well as in plants by modifying the motility and ability for biofilm formation of the microorganisms. Pseudomonas-derived surfactants can contribute to biological activity on plant and root surfaces by promoting the availability and uptake of nutrients and microbial metabolites. Antibiotic activity of biosurfactants against pathogenic microbes may have an impact on inter- and intraspecific competition during plant colonization, self-defence and on pathogenesis (D'EAs et al., 2010).
Another metabolite from lipopeptide producing members of Pseudomonas with confirmed antibiotic activity is massetolide A as it was reported by RAAIJMAKERS et al. (2010). Compounds related to massetolide A, such as the isomers of massetolide $\mathrm{E}, \mathrm{G}$, and $\mathrm{H}$, have been found during the investigations of KRÜGER (2008) in P. veronii PAZ1. A massetolide A-producing strain, as well as the purified compound, inhibited $P$. infestans on tomato plants which not only prevented infection of leaves, but also significantly reduced the expansion of existing infections as well as the formation of sporangia (TRAN et al., 2007). It was also shown that a massetolide A - deficient mutant had a weak suppressive effect against the target pathogen. This indicated an increased systemic resistance of tomato plants elicited by the applied bacteria. Further studies showed a concentration-dependent direct impact of massetolide A on oomycete pathogens. The effects included encystment of zoospores and autoaggregation at low concentrations and disruption of membranes of the zoospores within a few minutes at higher concentrations (DE SouZA et al., 2003; VAN DE MorTEL et al., 2009). The massetolides $A$ to $H$ have been detected in marine members of Pseudomonas which exhibited in vitro antimicrobial activity against species of Mycobacterium (GERARD et al., 1997). It can be supposed that the massetolides $\mathrm{E}, \mathrm{G}$, and $\mathrm{H}$ from $P$. veronii PAZ1 detected by KRÜGER (2008) also possess an inhibitory activity against fungi and oomycetes and, together with the antibiotically active main CLP viscosin, operate similarly as described for massetolide A. Further studies are necessary to investigate the specific properties of the identified single CLPs, especially those from the massetolides $\mathrm{E}, \mathrm{G}$, and $\mathrm{H}$, their antibiotic activity, and their influence on the interaction between the bacteria and pathogenic strains of $P$. alni on alder plants.

\section{Acknowledgement}

The authors are grateful to Mrs. MARLIEs Karaus, Mrs. Heidrun Mattauch, Mrs. Roswitha Rüdiger and Mrs. Michaela West for their accurate and reliable technical assistance.

\section{References}

Adams, G. C., M. Catal, L. Trummer, E. M. Hansen, P. REESER and J. J. WORRALl (2008): Phytophthora alni subsp. uniformis found in Alaska beneath thinleaf alders. Plant Health Progress. doi:10.1094/PHP-20081212-02-BR

Andersen, J. B., B. Koch, T. H. Nielsen, D. Sörensen, M. Hansen, O. Nybroe, C. Christophersen, J. SöRensen, S. Molin and M. Givskov (2003): Surface motility in Pseudomonas sp. DSS73 is required for efficient biological containment of the root-pathogenic microfungi Rhizoctonia solani and Pythium ultimum. Microbiology 149, 37-46.

Brasier, C. M., J. Rose and J. N. GiBBs (1995): An unusual Phytophthora associated with alder mortality in Britain. Plant Pathology 44, 999-1007.

Brasier, C. M., D. E. CoOKe and J. M. DunCAN (1999): Origin of a new Phytophthora pathogen through interspecific hybridization. Proc. Natl. Acad. Sci. USA 96, 5878-5883. 
CECH, T. (2001): Phytophthora-Erlensterben. http://bfw.ac. at/400/1511.html

D'Aes, J., K. De Maeyer, E. Pauwelyn and M. Höfte (2010): Biosurfactants in plant-Pseudomonas interactions and their importance to biocontrol. Environm. Microbiol. Rep. 2, 359-372.

De Boer, W., L. B. Folman, R. C. Summerbell and L. BoDDY (2005): Living in a fungal world: impact of fungi on soil bacterial niche development. FEMS Microbiol. Rev. 29, 795-811.

De BruiJn, I., M. J. D. De Kock, M. Yang, P. DE WAARD, T. A. VAN BEEK and J. M. RAAIJMAKERS (2007): Genomebased discovery, structure prediction and functional analysis of cyclic lipopeptide antibiotics in Pseudomonas species. Mol. Microbiol. 63, 417-428.

De Souza, J. T., M. DE Boer, P. DE WAARd, T. A. van BeEk and J. M. RAAIJMAKERS (2003): Biochemical, Genetic and Zoosporicidal Properties of Cyclic Lipopeptide Surfactants Produced by Pseudomonas fluorescens. AEM 69, 7161-7172.

Ganeshan, G. and A. M. Kumar (2005): Pseudomonas fluorescens, a potential bacterial antagonist to control plant diseases. Jour. Plant Interactions 1, 123-134.

Gerard, J., R. Lloyd, T. Barsby, P. M. Haden, M. T. Kelly and R. J. ANDERSEN (1997): Massetolides A-H, antimycobacterial cyclic depsipeptides produced by two pseudomonads isolated from marine habitats. J. Nat. Prod. 60, 223-229.

GiBBS, J. N. (2003): Management and control of Phytophthora disease of alder in Europe. In: J. GIBBS, C. v. DIJK, and J. WeBber: Forest Commission Bulletin 126, pp 73-78, Forest Commission Edinburgh.

GiBBS, J., C. van DiJK and J. WeBber (2003): Phytophtho$r a$ disease of alder in Europe. Forestry Commission Bulletin 126, Forestry Commission Edinburgh.

HAAS, D. and G. DÉFAGO (2005): Biological control of soilborne pathogens by fluorescent pseudomonads. Nat. Rev. Microbiol. 3, 307-319.

HöFte, M. and N. AltieR (2010): Fluorescent pseudomonads as biocontrol agents for sustainable agricultural systems. Res. Microbiol 161, 464-471.

Ioos, R., A. Andrieux, B. MarçAis and P. Frey (2006): Genetic characterization of the natural hybrid species Phytophthora alni as inferred from nuclear and mitochondrial DNA analyses. Fungal Genet. Biol. 43, 511-529.

KRÜGER, L. (2008): Interaktion zwischen vergesellschafteten Bodenmikroorganismen Pseudomonas sp. PAZ1 und Phytophthora alni AL5 sowie Wirkung der sekundären Metaboliten auf Erlenjungpflanzen. Diplomarbeit, Institut für Ökologie, TU Berlin.

Laycock, M. V., P. D. Hildebrand, P. Thibault, J. A. WalTER and J. L. C. WRIGHT (1991): Viscosin, a Potent Peptidolipid Biosurfactant and Phytopathogenic Mediator Produced by a Pectolytic Strain of Pseudomonas fluorescens. J. Agric. Food Chem. 39, 483-489.
Le, C. N., M. KRUiJT and J. M. RaAiJMakers (2012): Involvement of phenazines and lipopeptides in interactions between Pseudomonas species and Sclerotium rolfsii, causal agent of stem root disease on groundnut. J. Appl. Microbiol. 112, 390-403.

Musch, P. and T. Alatossava (2002): Several pseudomonads, associated with the cultivated mushrooms Agaricus bisporus or Pleurotus sp., are hemolytic. Microbiol. Res. 157, 311-315.

NAZIR, R., J. A. WARmink, H. Boersma and J. D. van Elsas (2010): Mechanisms that promote bacterial fitness in fungal-affected soil microhabitats. FEMS Microbiol. Ecol. 71, 169-185

Nielsen, T. H., C. Christophersen, U. Anthoni and J. SöREnsen (1999): Viscosinamide, a new cyclic depsipeptide with surfactant and antifungal properties produced by Pseudomonas fluorescens DR54. J Appl. Microbiol. 87, 80-90.

Podile, A. R. and G. K. Kishore (2006): Plant growthpromoting rhizobacteria. In: Gnanamanickam, S.: Plant-Associated Bacteria. Springer, Dordrecht, 195-206.

RAAIJMAKERS, J. M., I. DE BRUIJN and M. J. DE KoCK (2006): Cyclic lipopeptide production by plant-associated Pseudomonas spp.: diversity, activity, biosynthesis, and regulation. Mol. Plant-Microbe Interactions 19, 699-710.

RAAiJMakers, J. M., I. De BruiJn, O. Nybroe and M. ONGENA (2010): Natural functions of lipopeptides from Bacillus and Pseudomonas: more than surfactants and antibiotics. FEMS Microbiol. Rev. 34, 1037-1062.

Schneck, V. and I. ZASPEL (2006): Susceptibility to Phytophthora alni and the growth performance of common alder (Alnus glutinosa Gaertn.) progenies. In: OszAKo, T. and S. WOODWARD (eds.): Possible limitation of decline phenomena in broadleaved stands. ISBN 8387647-56, Warsawa, 135-141.

Tran, H., A. Ficke, T. Assimmwe, M. Höfte and J. M. RAAIJMAKERS (2007): Role of the cyclic lipopeptide massetolide A in biological control of Phytophthora infestans and in colonization of tomato plants by Pseudomonas fluorescens. New Phytologist 175: 731-742.

Van de Mortel, J. E., H. Tran, F. Govers and J. M. RAAIJMAKERS (2009): Cellular responses of the late blight pathogen Phytophthora infestans to cyclic lipopeptide surfactants and their dependence on G proteins. Appl. Environm. Microbiol. 75, 4950-4957.

WebBer, J., J. GIBBS and S. HENRY (2004): Phytophthora Disease of Alder. Forestry Commission Information Note Dec 2004.

WHIPPS, J. M. (2001): Microbial interactions and biocontrol in the rhizosphere. J. Exp. Bot. 52, 87-511. 